\title{
CHARACTERIZATION OF A POROUS NICKEL-TITANIUM ALLOY PRODUCED WITH SELF-PROPAGATING HIGH-TEMPERATURE SYNTHESIS
}

\author{
KARAKTERIZACIJA POROZNE NIKELJ-TITANOVE ZLITINE, \\ IZDELANE S SPONTANO NAPREDUJOČO \\ VISOKOTEMPERATURNO SINTEZO
}

\author{
Gul Tosun', Musa Kilic², Latif Ozler ${ }^{3}$, Nihat Tosun ${ }^{3}$ \\ ${ }^{1}$ Frrat University, Technology Faculty, Mechanical Engineering Department, 23119 Elazig, Turkey \\ ${ }^{2}$ Batman University, Technology Faculty, Mechanical and Manufacturing Engineering, 72060 Batman, Turkey \\ ${ }^{3}$ Firat University, Engineering Faculty, Mechanical Engineering Department, 23119 Elazig, Turkey \\ gultosun@firat.edu.tr \\ Prejem rokopisa - received: 2017-09-24; sprejem za objavo - accepted for publication: 2018-01-25
}

doi:10.17222/mit.2017.156

\begin{abstract}
The porous NiTi shape-memory alloy (SMA) is a promising biomaterial due to its attractive mechanical property and proper biocompatibility. In this research, the effects of the production parameters on the porosity of the above SMA were investigated using self-propagating high-temperature synthesis (SHS). Powders containing 50.5 atomic percent of Ni and 49.5 atomic percent of $\mathrm{Ti}$ were blended for $24 \mathrm{~h}$ and cold pressed at pressures of (100, 150 and 200) MPa. After that, NiTi-alloy green compacts were synthesized with the SHS process at different preheating temperatures of $(200,250$ and 300$){ }^{\circ} \mathrm{C}$, while some of these samples were sintered. The effects of the production parameters, namely, the heat treatment, pressure and preheating temperature on the microstructure and porosity were examined. Microhardness tests were done in order to evaluate the mechanical properties. In addition to $\mathrm{NiTi}$, there were other secondary intermetallic compounds $\left(\mathrm{NiTi}_{2}, \mathrm{Ni}_{3} \mathrm{Ti}_{1}\right.$ and $\left.\mathrm{Ni}_{4} \mathrm{Ti}_{3}\right)$ as the base phases of the microstructure. The porosity was changed depending on the process parameters. The porosities of the synthesized products were obtained in a range of 38.6-56 volume percent. It was observed that the preheating temperature had an important effect on the pore-size distribution of the NiTi product. The sintering heat treatment changed the distribution of the phases in the microstructure. The main phase of the porous NiTi alloy was the NiTi phase together with the $\mathrm{Ni}_{3} \mathrm{Ti}_{2}$ and $\mathrm{Ni}_{2} \mathrm{Ti}$ secondary phases.

Keywords: biomaterials, high-temperature synthesis (SHS), powder metallurgy, porosity, microstructure, hardness
\end{abstract}

Porozne Ni-Ti zlitine z oblikovnim spominom (SMA; angl.: Shape Memory Alloys) so zaradi privlačnih mehanskih lastnosti in primerne biokompatibilnosti obetaven biomaterial. V članku avtorji opisujejo raziskavo vpliva tehnoloških parametrov na poroznost SMA, ki so jo izdelali s pomočjo spontano napredujoče visokotemperaturne sinteze (SHS; angl.: self-propagating high-temperatures synthesis). Mešanico prahov Ni $(50,5 \%)$ in Ti $(49,5 \%)$ so mešali 24 ur in jo nato hladno stisnili pri tlakih $(100,150$ in 200) MPa. Potem so surovce iz Ni-Ti zlitine konsolidirali s SHS procesom pri različnih temperaturah predgrevanja: $(200,250$ in 300$){ }^{\circ} \mathrm{C}$. Del vzorcev pa je bil zgoščen s sintranjem. Nato so analizirali vpliv tehnoloških parametrov sinteze (temperature predgretja in toplotne obdelave, tlaka) na mikrostrukturo in poroznost. Mehanske lastnosti so ovrednotili z meritvami mikrotrdote. Poleg NiTi kot osnovne faze so se v mikrostrukturi zlitine pojavljale še sekundarne faze, kot so intermetalne spojine $\mathrm{NiTi}_{2}, \mathrm{Ni}_{3} \mathrm{Ti}$ in $\mathrm{Ni}_{4} \mathrm{Ti}_{3}$. Poroznost je bila odvisna od procesnih parametrov. Poroznosti sintetizirane zlitine so se gibale med 38,6 in 56,0 prostorninskih deležev. Ugotovili so, da ima temperatura predgrevanja pomemben vpliv na velikostno porazdelitev por Ni-Ti produkta. Sintranje je spremenilo porazdelitev faz v mikrostrukturi. V sintetiziranih poroznih $\mathrm{Ni}$-Ti zlitinah je kot glavna faza nastopala faza $\mathrm{NiTi}$ s sekundarnima fazama $\mathrm{Ni}_{3} \mathrm{Ti}_{2}$ in $\mathrm{Ni}_{2} \mathrm{Ti}_{\text {. }}$

Ključne besede: biomateriali, visokotemperaturna sinteza (SHS), metalurgija prahov, poroznost, mikrostruktura, trdota

\section{INTRODUCTION}

Discovering a cost-efficient production procedure for innovative metal alloys is one of the most significant improvement in scientific disciplines. ${ }^{1}$ The nickel-titanium alloy with a near-equiatomic concentration is well known for its shape-memory effect (SME). ${ }^{2}$ NiTi SMAs have been successfully used in many industries such as engineering, medical industry, space researches, automotive, micro-electromechanical and orthopedic applications. As they have superior mechanical features, for example, superelasticity (SE), SME, biocompatibility, they are appropriate for surgical operations and brackets, hard-tissue replacements and corrosion-resistant im- plants. ${ }^{3-7}$ Highly porous NiTi is commonly produced with several techniques such as melting, casting, reactive sintering, conventional sintering, SHS, HIP (hot ýsostatic pressing) with gas entrapment, capsule-free hot isostatic pressing, spark plasma sintering and HIP with space holders. ${ }^{8,9}$ These techniques, however, only entail rounded/sponge-like pore geometries. ${ }^{10,11}$

Furthermore, the NiTi produced with the SHS treatment has a larger porosity and linear channels. ${ }^{12}$ The SHS procedure for manufacturing porous intermetallic compounds has several advantages such as time, energy savings and purity of the reaction product. ${ }^{13}$ To form a compact from powders, routes such as powder blending, cold pressing and sintering are usually followed. ${ }^{14}$ The 
following phenomena generally occur during the SHS of NiTi SMAs; preheating, ignition, propagation of the combustion wave front and cooling. ${ }^{13}$

Several phenomena cause porosity during the SHS process: a modified volume because of a crystal-lattice re-ordering, the Kirkendall effect, thermal migration, gas porosity or residual porosity after the pressing. ${ }^{14}$

The sintering temperature is first reached outside and later inside; consequently, NiTi is first produced in the ectotheca of a sample. Furthermore, regional melting/ collapsing does not happen simply because of a direct contact under an inert atmosphere (argon) with high pressure during the process. At the increased sintering temperature, exothermic reactions take place inside the sample of $\mathrm{Ni}$ and $\mathrm{Ti}$ :

$$
\begin{gathered}
\mathrm{Ni}+\mathrm{Ti} \rightarrow \mathrm{NiTi}+67 \mathrm{~kJ} / \mathrm{mol} \\
\mathrm{Ni}+\mathrm{Ti} \rightarrow \mathrm{Ti}_{2} \mathrm{Ni}+83 \mathrm{~kJ} / \mathrm{mol} \\
\mathrm{Ni}+\mathrm{Ti} \rightarrow \mathrm{Ni}_{3} \mathrm{Ti}+140 \mathrm{~kJ} / \mathrm{mol} \\
\mathrm{Ni}+\mathrm{Ti} \rightarrow \mathrm{Ni}_{4} \mathrm{Ti}_{3} \text { theat }
\end{gathered}
$$

The reactions cause local melting due to the local overheating in these regions. Consequently, the pores expand and coalesce and the interior small pores convert into one or a few great pores when the sintering temperature is enhanced. ${ }^{12}$

The present work focuses on the influence of production parameters and heat treatment on the microstructure and porosity of porous NiTi made with SHS.

\section{EXPERIMENTAL PART}

The powders of $\mathrm{Ti}(99.5 \%)$ and $\mathrm{Ni}(99.8 \%)$ supplied by Alfa Inc., USA, were used to produce NiTi (Table 1). The Ni and $\mathrm{Ti}$ powders with a combination of $\mathrm{Ni}$ :Ti $=$ 50:50 \% were blended in an argon-gas sealed container using a spherical-ball mill for $24 \mathrm{~h}$. Cylindrical green bulks had a diameter of $12 \mathrm{~mm}$ and a height of approximately $10 \mathrm{~mm}$. They were produced via uniaxial cold pressing at pressures of (100, 150 and 200) $\mathrm{MPa}$

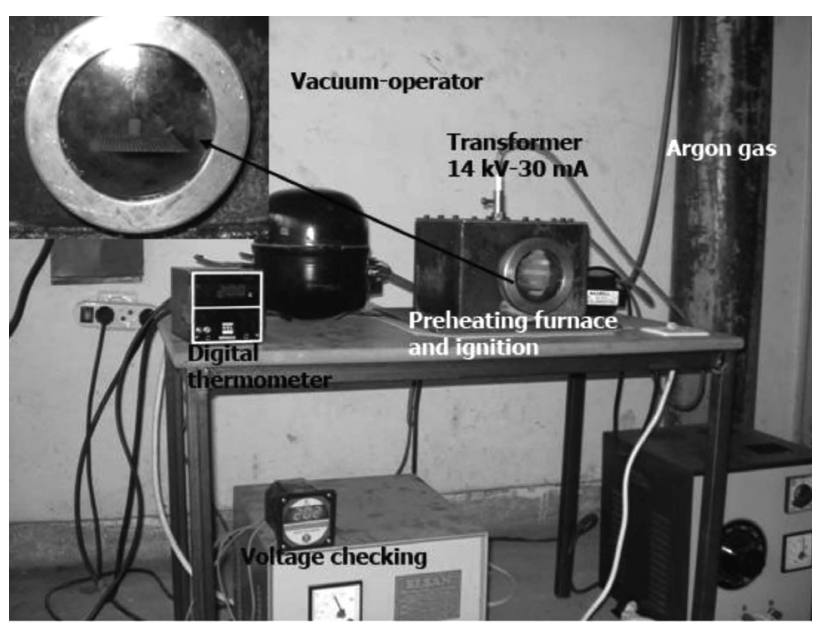

Figure 1: Experimental set-up using a hydraulic press. During the experiments, the preheating temperatures were $(200,250$ and 300$){ }^{\circ} \mathrm{C}$ under an atmosphere of inert gas (Figure 1). The preheated green bodies were ignited at the endpoint via a tungsten coil in a furnace. Afterwards, the synthesizing reaction was actualized; we waited until the temperature of the specimens was equal to room temperature in the reaction chamber. Some samples were sintered at a heating rate of $15^{\circ} \mathrm{C} / \mathrm{min}$, a temperature of $850^{\circ} \mathrm{C}$ and a duration of $3 \mathrm{~h}$ in a Protherm sintering furnace. During the experiments, the ignition temperatures were measured in a range of $607-1238{ }^{\circ} \mathrm{C}$ depending on the process parameters.

The microstructure investigations were done with a scanning electron microscope (SEM) and an optical microscope. The total porosity of the samples $(\varepsilon)$ was determined with the following formula:

$$
\varepsilon=\left(1-\frac{\rho}{\rho_{0}}\right) \times 100
$$

where $\rho$ is the density of the sample and $\rho_{0}$ is the corresponding theoretical density of the sample. The sample density was calculated by measuring the weight and dimensions of the specimens. The theoretical density of the NiTi alloy with $x=50.5 \% \mathrm{Ni}$ was 6.21 $\mathrm{g} / \mathrm{cm}^{3}$. The porosity and density of sintered and nonsintered samples were measured with the Archimedes method as specified in the ASTMB962-08 standard. After polishing, etching processes of the NiTi specimens were done with a mixture of $10 \% \mathrm{HF}$ and $5 \%$ $\mathrm{HNO}_{3}$ in water. The optical microscope (AlltionNIM100) and SEM (LEO Evo-40VP) were used to analyze the pore characteristics of the NiTi products and the microstructure. The chemical composition of the samples was specified with an energy-dispersive-spectroscopy (EDS) analysis.

Table 1: Features of $\mathrm{Ti}$ and Ni powders

\begin{tabular}{|l|c|c|}
\hline \multicolumn{1}{|c|}{ Features of the material } & Nickel & Titanium \\
\hline Purity $(\%)$ & 99.8 & 99.5 \\
\hline Specific gravity $(\mathrm{g} / \mathrm{mol})$ & 58.71 & 47.9 \\
\hline Powder dimension $(\mathrm{mesh})$ & -325 & -325 \\
\hline Melting temperature $\left({ }^{\circ} \mathrm{C}\right)$ & 1453 & 1680 \\
\hline Specific weight $\left(\mathrm{g} / \mathrm{cm}^{3}\right)$ & 8.9 & 4.507 \\
\hline Boiling temperature $\left({ }^{\circ} \mathrm{C}\right)$ & 2832 & 3260 \\
\hline Ignition temperature $\left({ }^{\circ} \mathrm{C}\right)$ & $\begin{array}{c}\text { Not } \\
\text { determined }\end{array}$ & 250 \\
\hline
\end{tabular}

\section{RESULTS AND DISCUSSION}

No distortion or surface cracks were observed on the produced compacts. Figure 2 shows an optical macrograph of the porous structure produced by synthesizing. Ignition channels occurred as vertical circles on the electrode axis. As can be seen, the porous NiTi SMA produced in this research exhibits a homogeneous pore distribution. The pores in the produced NiTi are almost 


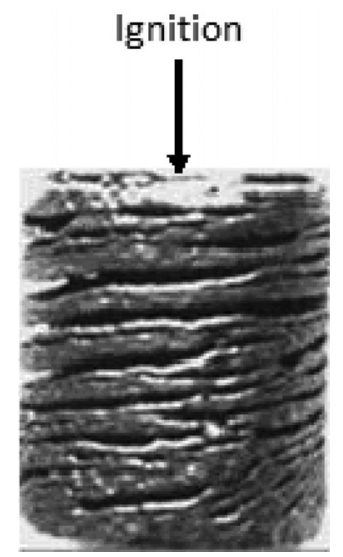

Figure 2: Macrograph of a synthesized porous, solid, cylindrical NiTi sample

three-dimensionally interdependent, and the sample has an open porous structure. ${ }^{15}$ The pores are homogeneously distributed on the cross-section and their edges are not sharp. The rounded shape reduces the stress concentration at the edges of the pores, increasing the mechanical strength and improving the shape-memory behavior. Therefore, to check the pore character and enhance the mechanical properties, the superelasticity and biocompatibility of these SMAs are of key importance. ${ }^{2}$

In the microstructure, the single phase instrumental for the necessary superelasticity is NiTi. Therefore, any unwanted phases and unreacted $\mathrm{Ni}$ need to be removed to develop its superelasticity for improving its biomechanical compatibility. Mechanical properties should be improved without reducing the porosity because a reduced porosity affects the ingrowth of the bone tissue. Commonly, if the sintering temperature, or the combustion temperature, is high enough, a product with a single phase is obtained. ${ }^{16}$

When the microstructures of the produced samples are investigated, the NiTi phase is the main phase, as seen in Figure 3. In addition, secondary phases such as $\mathrm{Ni}_{2} \mathrm{Ti}, \mathrm{Ni}_{3} \mathrm{Ti}$ or, in some cases, even elemental $\mathrm{Ni}$ in variable quantities are observed (Figure 4). ${ }^{6,15,17,18}$ In the microstructure images of the samples, the NiTi matrix is grey, the $\mathrm{Ni}_{3} \mathrm{Ti}_{2}$ or $\mathrm{Ni}_{4} \mathrm{Ti}_{3}$ phases are light grey and the $\mathrm{NiTi}_{2}$ phase is corner-shaped and dark grey. ${ }^{14}$

Micrographs in Figures 3, 4 and 5, show the effect of the cold-compaction pressure on the microstructure. The combustion properties, mostly associated with the formation of the NiTi intermetallic obtained with the SHS procedure, are the preheating temperature and the initial specimen density. It was found that in the specimens with a low green density and at a cold-compaction pressure of $100 \mathrm{MPa}$, the main phase was NiTi and the secondary phase was $\mathrm{Ni}_{3} \mathrm{Ti}_{2}$ (Figure 3a). The NiTi phase and uniform $\mathrm{Ni}_{3} \mathrm{Ti}_{2}$ and $\mathrm{Ni}_{2} \mathrm{Ti}$ phase islands were also seen when the green density, or the cold-compaction pressure, was increased. When the pressure was increased to $150 \mathrm{MPa}$ (Figure $\mathbf{3 b}$ ), interconnected islands disappeared. When the pressure became $200 \mathrm{MPa}$,
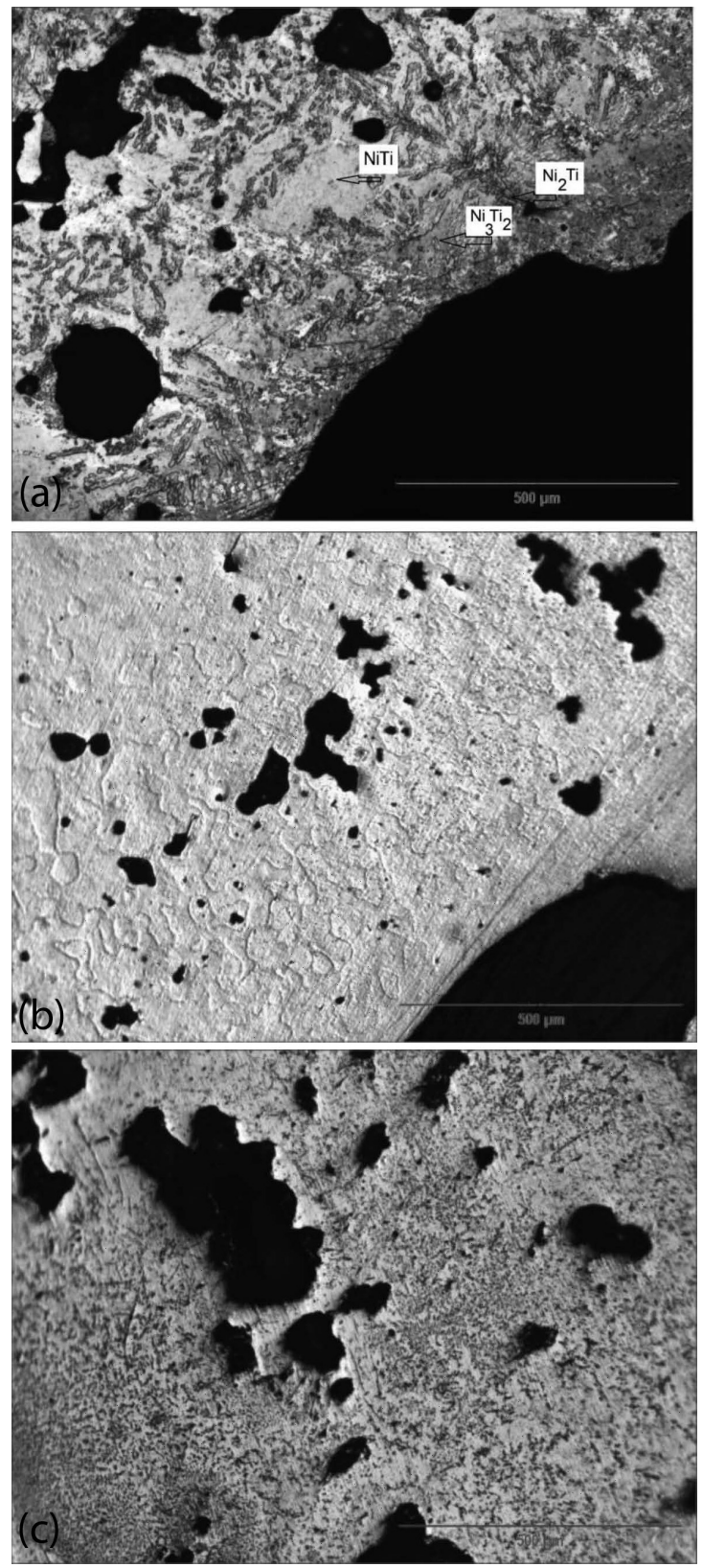

Figure 3: Specimens at the preheating temperature of $200{ }^{\circ} \mathrm{C}$, nonsintered and at pressures of: a) $100 \mathrm{MPa}$, b) $150 \mathrm{MPa}$, c) $200 \mathrm{MPa}$

interconnected islands re-occurred (Figure 3c). When the cold-compaction pressure was increased to $200 \mathrm{MPa}$, the NiTi phase was dominant while the amount of $\mathrm{Ni}_{3} \mathrm{Ti}_{2}$ increased and the amount of $\mathrm{Ni}_{2} \mathrm{Ti}$ decreased.

Figure 4 shows a SEM graph and EDX analysis of interconnected islands for the samples produced at 100 $\mathrm{MPa}$.

At the preheating temperature of $250{ }^{\circ} \mathrm{C}$, it was seen that the main phase was $\mathrm{Ni}_{3} \mathrm{Ti}_{2}$ and the secondary phases were $\mathrm{NiTi}$ and $\mathrm{Ni}_{2} \mathrm{Ti}$ in the specimens with a low green density at the $100 \mathrm{MPa}$ cold-compaction pressure (Figure 5a). An increased amount of the NiTi phase and a decreased amount of the uniform $\mathrm{Ni}_{3} \mathrm{Ti}_{2}$ and $\mathrm{Ni}_{2} \mathrm{Ti}$ phase 

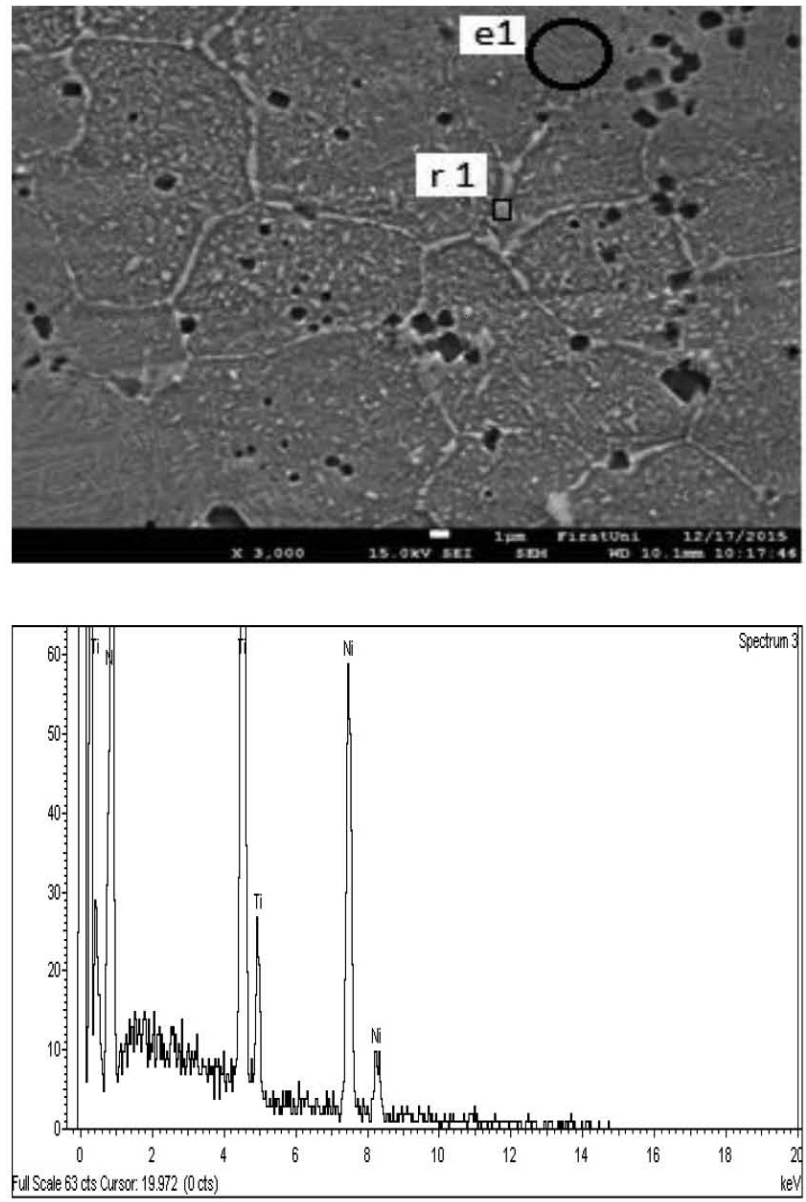

\begin{tabular}{|l|ll|}
\hline Element & Weight\% & Atomic\% \\
Ti K & 47.09 & 52.17 \\
Ni K & 52.91 & 47.83 \\
Total & 100.00 & \\
\hline
\end{tabular}

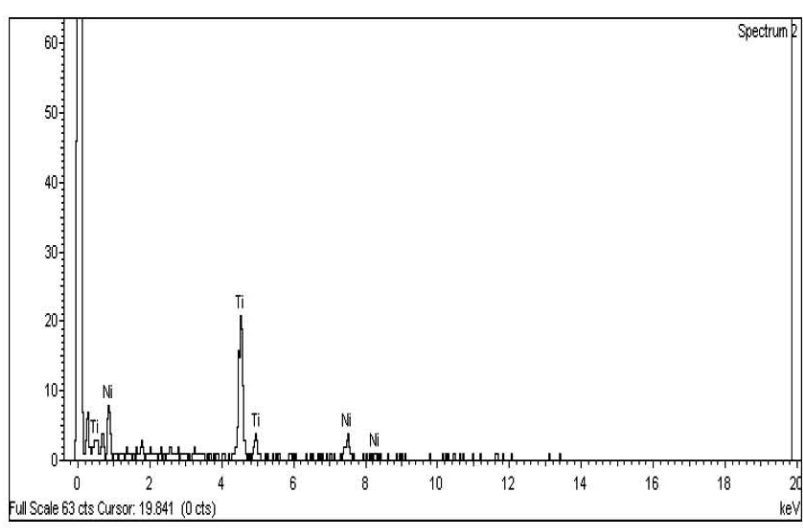

\begin{tabular}{|l|ll|}
\hline Element & Weight $\%$ & Atomic\% \\
Ti K & 62.48 & 67.12 \\
Ni K & 37.52 & 32.88 \\
Totals & 100.00 & \\
\hline
\end{tabular}

Figure 4: a) pressure of $100 \mathrm{MPa}$, preheating temperature of $300{ }^{\circ} \mathrm{C}$, a non-sintered specimen, b) e1 EDX, c) r1 EDX
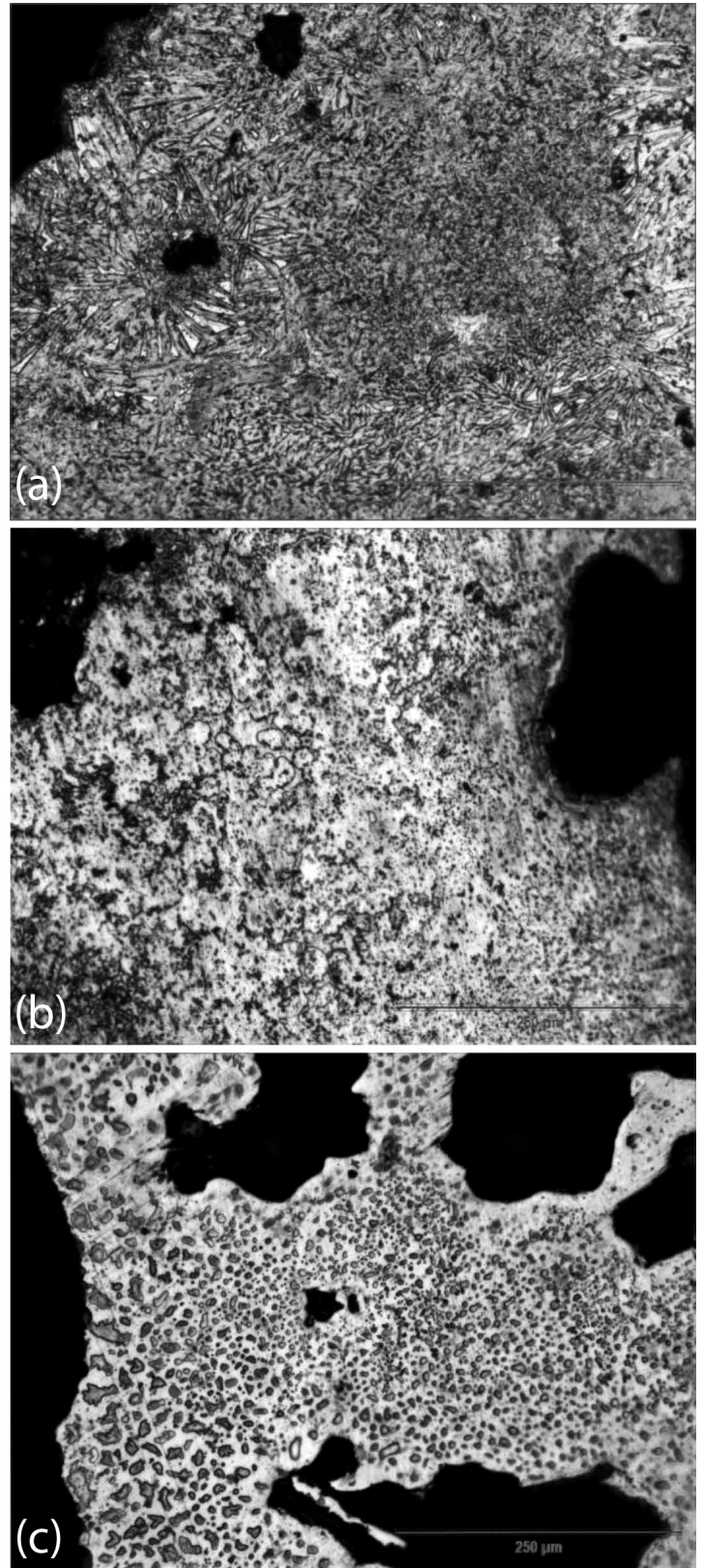

Figure 5: Specimens at the preheating temperature of $250{ }^{\circ} \mathrm{C}$, nonsintered and at pressures of: a) $100 \mathrm{MPa}$, b) $150 \mathrm{MPa}$, c) $200 \mathrm{MPa}$

islands were also seen when the green density, or the cold-compaction pressure, was increased. When the pressure was increased to $150 \mathrm{MPa}$ (Figure 5b), interconnected islands decreased. When the pressure became $200 \mathrm{MPa}$, interconnected islands re-increased (Figure 5c). When the cold-compaction pressure was increased to $200 \mathrm{MPa}$, the NiTi phase was dominant and the amounts of $\mathrm{Ni}_{3} \mathrm{Ti}_{2}$ and $\mathrm{Ni}_{2} \mathrm{Ti}$ increased.

The optical micrographs in Figure 6 show that the amount of the NiTi main phase of the SHS + sintering samples increases with the increasing preheating temperature. ${ }^{19} \mathrm{It}$ is seen that the porous products contain very small $\mathrm{NiTi}, \mathrm{NiTi}_{2}$ and $\mathrm{Ni}_{3} \mathrm{Ti}_{2}$ phases at the low preheating 

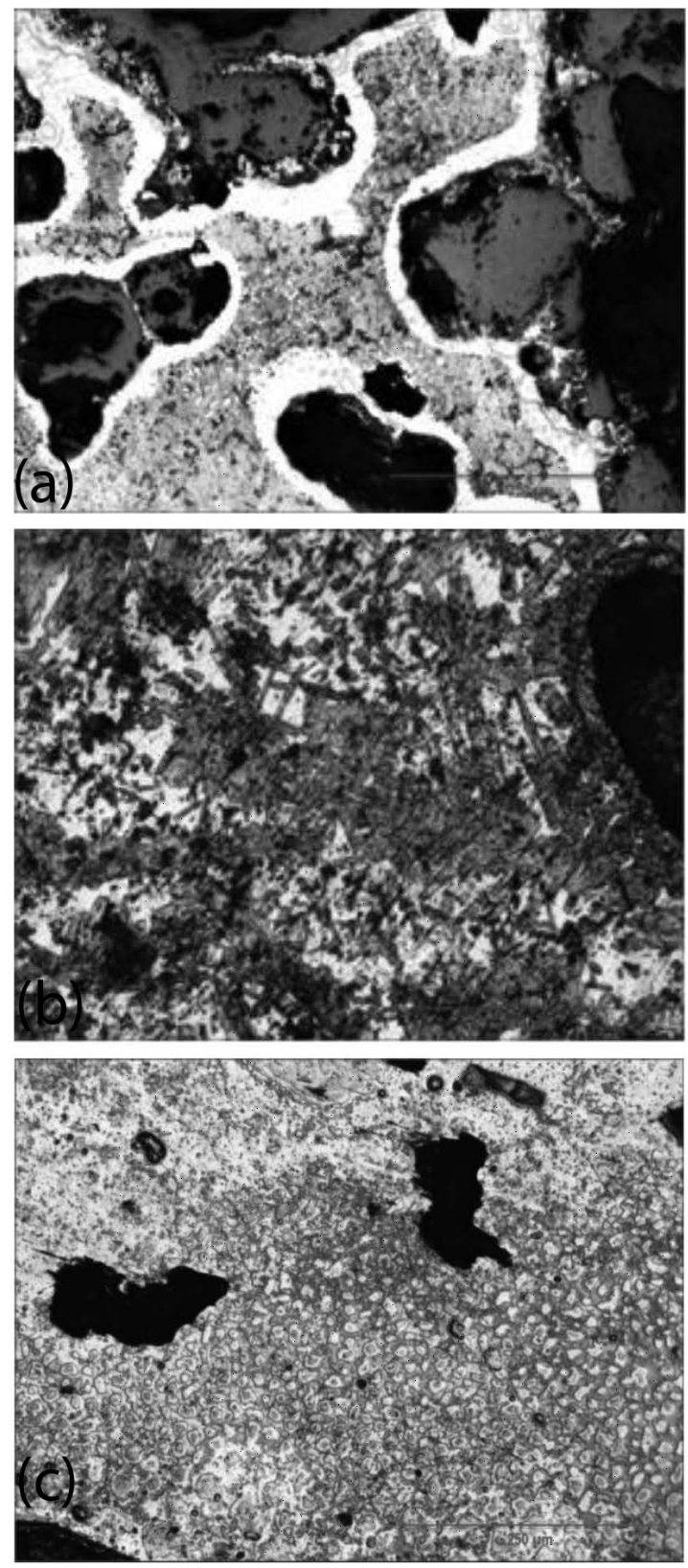

Figure 6: Specimens obtained with SHS + sintering at the pressure of $150 \mathrm{MPa}$ and preheating temperatures of: a) $200{ }^{\circ} \mathrm{C}$, b) $250{ }^{\circ} \mathrm{C}$ c) $300{ }^{\circ} \mathrm{C}$

temperature (Figure 6a) and the NiTi phase is surrounded by pores. There is not any homogeneity in the microstructure. When the preheating temperature is increased to $250{ }^{\circ} \mathrm{C}$ (Figure 6b), the amounts of NiTi and $\mathrm{NiTi}_{2}$ are increased, and $\mathrm{Ni}_{3} \mathrm{Ti}_{2}$ is decreased. When the preheating temperature is increased to $300{ }^{\circ} \mathrm{C}$ (Figure 6c), the amount of NiTi is decreased, $\mathrm{Ni}_{3} \mathrm{Ti}_{2}$ is increased and $\mathrm{NiTi}_{2}$ disappears.

The effect of the preheating temperature on the specimens at the $200 \mathrm{MPa}$ cold-compaction pressure was different. It was seen that the porous products contained the $\mathrm{NiTi}, \mathrm{NiTi}_{2}$ and Windsmatten-type $\mathrm{Ni}_{3} \mathrm{Ti}_{2}$ phases at a
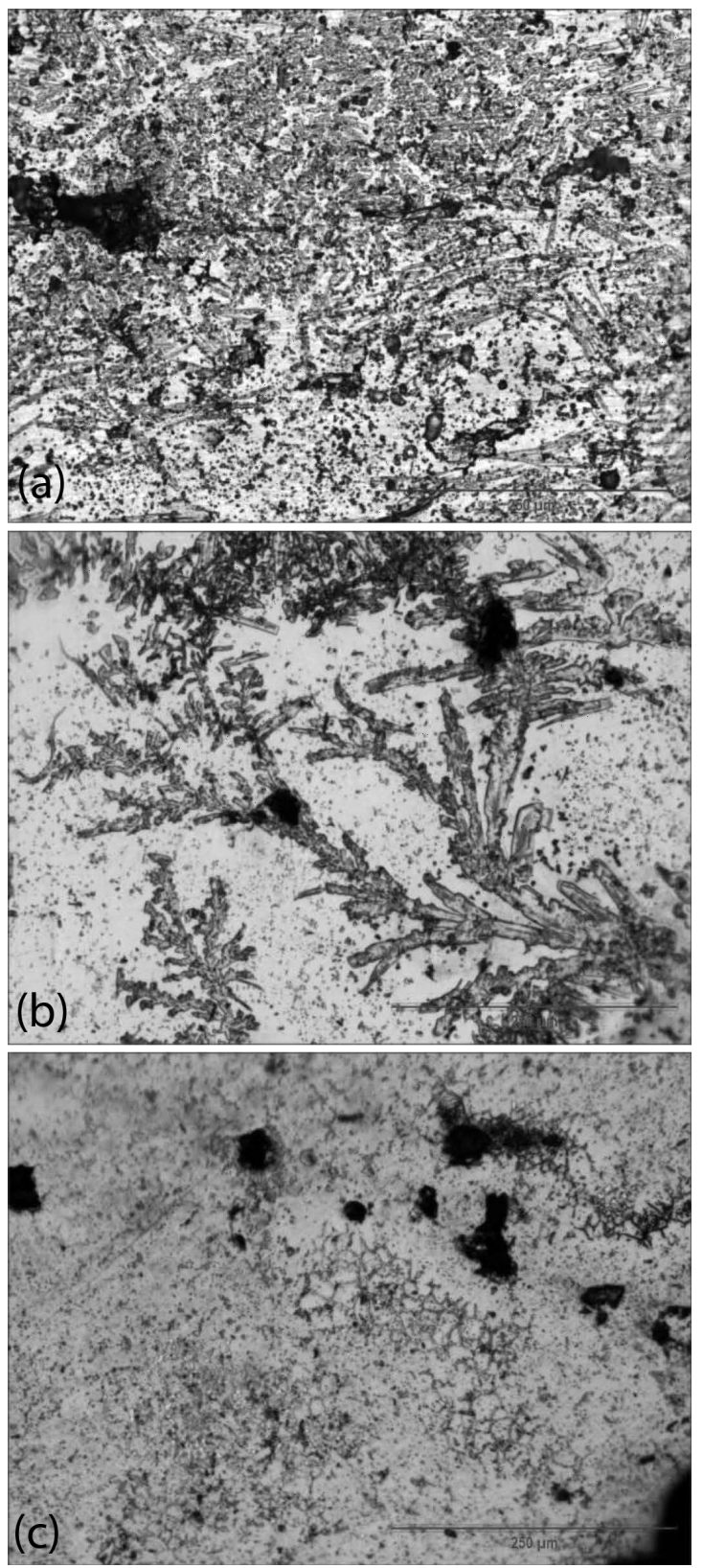

Figure 7: Specimens at the pressure of $200 \mathrm{MPa}$ and preheating temperatures of: a) $200{ }^{\circ} \mathrm{C}$, b) $250{ }^{\circ} \mathrm{C}$, c) $300{ }^{\circ} \mathrm{C}$

low preheating temperature (Figure 7a) When the preheating temperature was increased to $250{ }^{\circ} \mathrm{C}$ (Figure 7b), the amount of NiTi increased and $\mathrm{NiTi}_{2}$ disappeared. The Windsmatten-type $\mathrm{Ni}_{3} \mathrm{Ti}_{2}$ phase was seen. When the preheating temperature was increased to $300{ }^{\circ} \mathrm{C}$ (Figure 7c), the Windsmatten-type $\mathrm{Ni}_{3} \mathrm{Ti}_{2}$ phase disappeared.

When the preheating temperature was increased during SHS, the molten fraction of NiTi increased. The increase of the molten fraction caused the formation of both the micropores with a small size and the macropores with a large size. Consequently, it was observed that the preheating temperature had an important effect on the pore-size distribution of a NiTi product. ${ }^{15}$ 
The sintering heat treatment changes the distribution of the phases in the microstructure. The amount of the NiTi phase is high and the amounts of the $\mathrm{Ni}_{2} \mathrm{Ti}$ and $\mathrm{Ni}_{3} \mathrm{Ti}_{2}$ phase are low in the non-sintered samples. On the other hand, the amount of the NiTi phase decreases and the amounts of the $\mathrm{Ni}_{2} \mathrm{Ti}$ and $\mathrm{Ni}_{3} \mathrm{Ti}_{2}$ phase increase in the sintered samples (Figures 6 and 7).

The combustion channels are oriented perpendicularly to the combustion wave. The pore orientation depends on the point of ignition during SHS. ${ }^{2,3,19}$ It seems that some transient liquid phases are created due to locally high temperatures at the combustion front. As a result of a high temperature gradient along the combustion wave, the transient liquid phases extend perpendicularly to the combustion wave, resulting in elongated pores. ${ }^{3,19}$ There are sharp edges of the channels of the samples produced at the pressure of $100 \mathrm{MPa}$ and a low number of micropores (Figure 8). However, when the preheating temperature is increased, the edges of the channels are round, and the width and number of the micropores increase. Mechanical properties change depending on the orientation, shape and width of the channels. ${ }^{2,3}$ Because of this, the mechanical properties will probably improve. In addition, the micropores increase and the combustion channels become wide with the increasing pressure (Figure 8). Wide combustion
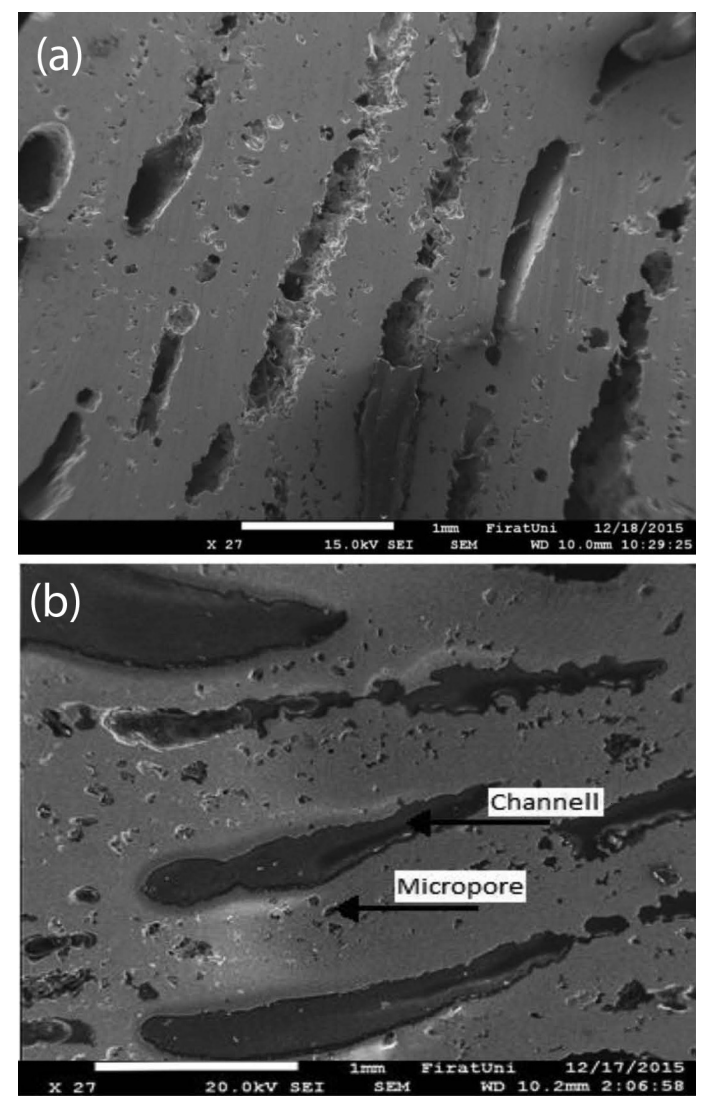

Figure 8: Specimens at the preheating temperature of $200{ }^{\circ} \mathrm{C}$, nonsintered, pressures of: a) $100 \mathrm{MPa}$, b) $200 \mathrm{MPa}$ channels are desired because the tissue progression into medical implants takes place in the combustion channels.

An important structural feature of a porous solid is the porosity (or, in other words, the relative density). Porosity greatly affects its mechanical properties. ${ }^{2,20}$

Figure 9 shows the porosity of non-sintered and sintered SHS specimens. The porosity changes depending on the process parameters. Bone-implant materials with a porosity in the range of 30-90\% and the optimum pore size of $100-400 \mu \mathrm{m}$ are ideal according to the references. ${ }^{21,22}$ Consequently, the porous NiTi alloy produced using microwave sintering and SHS have the appropriate porosity and pore size and will hopefully be used for bone implants. ${ }^{21,22}$ In our study, its porosity is in a range of $38.61-56.05 \%$.

In addition, the preheating temperature affects the porosity. The sintering process after the SHS negatively affects the porosity at the preheating temperature of $200{ }^{\circ} \mathrm{C}$. The porosity of the non-sintered samples is higher than that of the samples sintered at the $200{ }^{\circ} \mathrm{C}$ preheating temperature. On the contrary, the porosity of the non-sintered samples is lower than that of the samples sintered at the preheating temperatures of $250{ }^{\circ} \mathrm{C}$ and $300{ }^{\circ} \mathrm{C}$. When the preheating temperature is increased to $250{ }^{\circ} \mathrm{C}$, the porosity of the SHS samples decreases. When the preheating temperature is increased to $300{ }^{\circ} \mathrm{C}$, the porosity increases, except at $100 \mathrm{MPa}$ (Figure 9). When the preheating temperature is in-
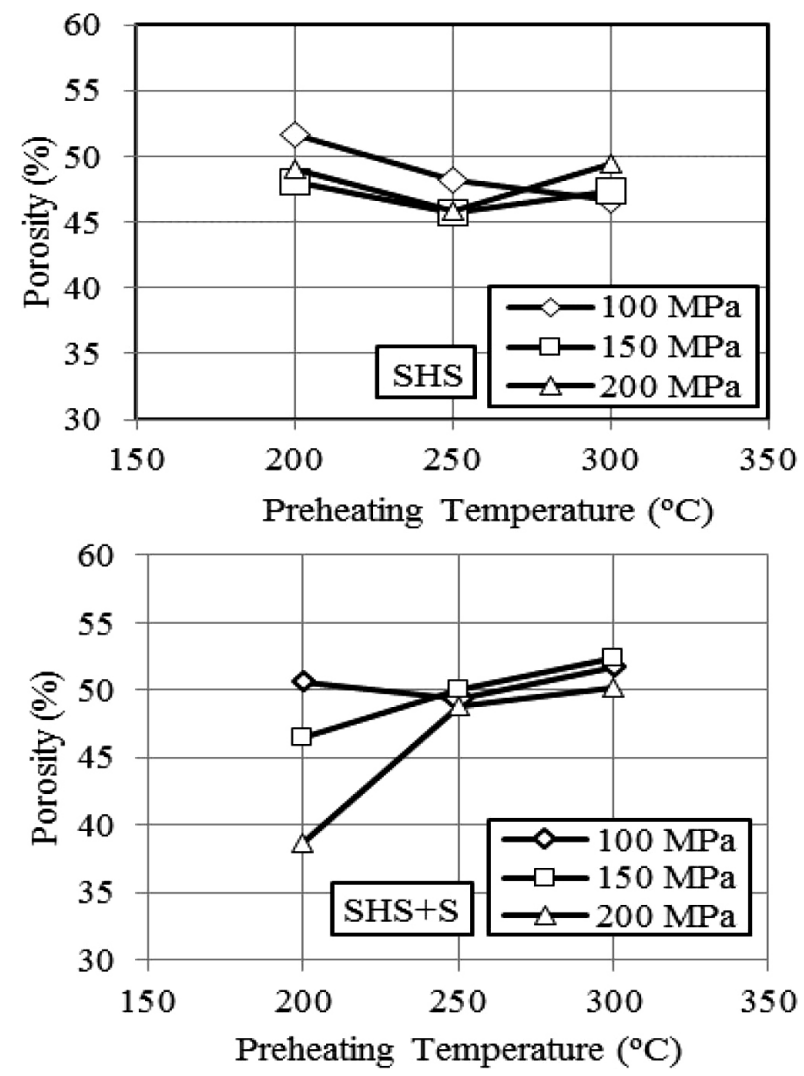

Figure 9: Porosity of the samples produced with SHS+sintering and SHS 

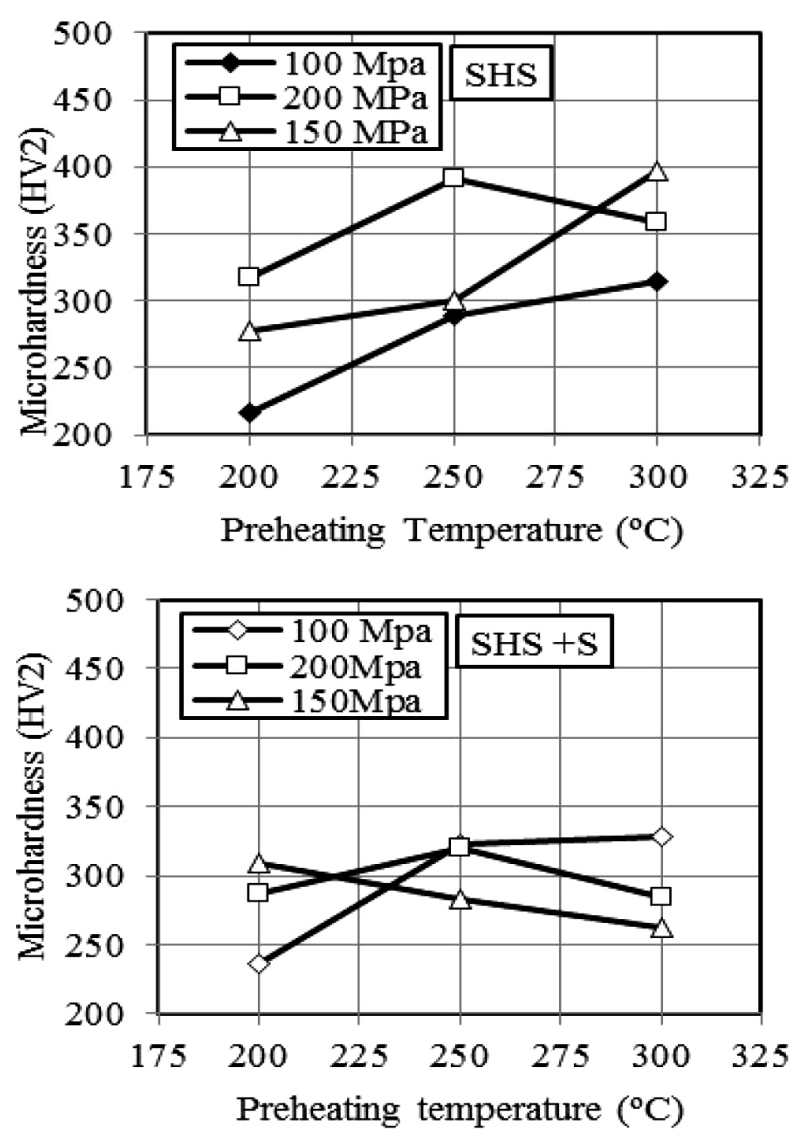

Figure 10: Microhardness versus preheating temperature for the samples produced with SHS and SHS + sintering

creased to $250{ }^{\circ} \mathrm{C}$, the porosity increases for the $\mathrm{SHS}+$ sintering samples except at $100 \mathrm{MPa}$. When the preheating temperature is increased to $300{ }^{\circ} \mathrm{C}$, the porosity increases for the SHS + sintering samples.

The hardness versus preheating temperature graphs for the SHS and SHS + sintering samples are shown in Figure 10. When the preheating temperature is increased to $250{ }^{\circ} \mathrm{C}$, the microhardness of the SHS samples increases. When the preheating temperature is increased to $300{ }^{\circ} \mathrm{C}$, the microhardness of the SHS samples increases, except at $200 \mathrm{MPa}$. When the preheating temperature is increased to $250{ }^{\circ} \mathrm{C}$, the microhardness increases, except for the SHS+sintering samples at $150 \mathrm{MPa}$. When the preheating temperature is increased to $300{ }^{\circ} \mathrm{C}$, the porosity increases, except for the SHS + sintering samples at $100 \mathrm{MPa}$. The hardness decrease in this condition is attributed to the secondary phases $\left(\mathrm{Ni}_{2} \mathrm{Ti}\right.$ and $\left.\mathrm{Ni}_{3} \mathrm{Ti}_{2}\right)$ observed with the optical microscope (Figures 6 and 7).

\section{CONCLUSIONS}

Porous NiTi specimens were manufactured with the SHS procedure. It is seen that the NiTi specimens produced with different manufacturing techniques and those produced with SHS show different amounts of porosity. The variance in the porosity and microstructure of the porous NiTi was examined by changing the production parameters and sintering heat treatment.

The porosities of the NiTi alloys change from $38.61 \%$ to $56.05 \%$ depending on the production parameters.

The porous NiTi alloys consisted of a nearly single NiTi phase with $\mathrm{Ni}_{3} \mathrm{Ti}_{2}$ and $\mathrm{Ni}_{2} \mathrm{Ti}$ secondary phases. For the non-sintered samples, it was observed that the interconnected $\mathrm{Ni}_{3} \mathrm{Ti}_{2}$ islands disappear at the pressure of $150 \mathrm{MPa}$, the NiTi phase is dominant and the amount of $\mathrm{Ni}_{3} \mathrm{Ti}_{2}$ increases at the pressure of $200 \mathrm{MPa}$. It can be shown that with the increasing preheating temperature, the amount of the NiTi main phase in the SHS + sintering samples increases. It was observed that the preheating temperature has an important effect on the pore-size distribution of a NiTi product. The sintering heat treatment changes the distribution of the phases in the microstructure. The amount of the NiTi phase is high and the amounts of the $\mathrm{Ni}_{2} \mathrm{Ti}$ and $\mathrm{Ni}_{3} \mathrm{Ti}_{2}$ phases are low in the non-sintered samples. On the other hand, the amount of the NiTi phase decreases and the amounts of the $\mathrm{Ni}_{2} \mathrm{Ti}$ and $\mathrm{Ni}_{3} \mathrm{Ti}_{2}$ phases increase for the sintered samples. The edges of the channels are round; their width and the number of micropores increase when the preheating temperature is increased.

The porosity changes depending on the process parameters. In our study, the porosity is in the range of 38.61-56.05\%. The preheating temperature affects the porosity. The sintering process after the SHS negatively affects the porosity at the preheating temperature of $200{ }^{\circ} \mathrm{C}$. The porosity of the non-sintered samples is higher than that of the sintered samples at the preheating temperature of $200{ }^{\circ} \mathrm{C}$. On the contrary, the porosity of the non-sintered samples is lower than that of the samples sintered the at the preheating temperatures of $250{ }^{\circ} \mathrm{C}$ and $300{ }^{\circ} \mathrm{C}$. When the preheating temperature is increased to $250{ }^{\circ} \mathrm{C}$, the porosity of the SHS samples decreases. When the preheating temperature is increased to $300{ }^{\circ} \mathrm{C}$, the porosity increases, except at $100 \mathrm{MPa}$. When the preheating temperature is increased to $250{ }^{\circ} \mathrm{C}$, the porosity of the SHS + sintering samples increases, except at $100 \mathrm{MPa}$. When the preheating temperature is increased to $300{ }^{\circ} \mathrm{C}$, the porosity of the SHS+sintering samples increases.

When the preheating temperature is increased to $250{ }^{\circ} \mathrm{C}$, the microhardness of the SHS samples increases. When the preheating temperature is increased to $300{ }^{\circ} \mathrm{C}$, the microhardness of the SHS samples increases, except at $200 \mathrm{MPa}$. When the preheating temperature is increased to $250{ }^{\circ} \mathrm{C}$, the microhardness of the SHS + sintering samples increases, except at $150 \mathrm{MPa}$. When the preheating temperature is increased to $300{ }^{\circ} \mathrm{C}$, the microhardness increases, except for the SHS + sintering samples at $100 \mathrm{MPa}$. 


\section{REFERENCES}

${ }^{1}$ A. Pozdnyakova, A. Giuliani, J. Dutkiewicz, A. Babutsky, A. Chyzhyk, J. A. Roether, F. Rustichelli, M. G. Ortore, Analysis of porosity in NiTi SMAs changed by secondary pulse electric current treatment by means of ultra small angle scattering and micro-computed tomography, Intermetallics, 18 (2010), 907-912, doi:10.1016/j.intermet. 2009.12.030

${ }^{2}$ S. K. Sadrnezhaad, S. A. Hosseini, Fabrication of porous NiTi-shape memory alloy objects by partially hydrided titanium powder for biomedical applications, Materials and Design, 30 (2009), 4483-4487, doi:10.1016/j.matdes.2009.05.034

${ }^{3}$ M. Kaya, N. Orhan, G. Tosun, The effect of the combustion channels on the compressive strength of porous NiTi shape memory alloy fabricated by SHS as implant material, Current Opinion in Solid State and Materials Science, 14 (2010) 21-25, doi:10.1016/j.cossms. 2009.07.002

${ }^{4}$ C. Bewerse, A. A. Emery, L. C. Brinson, D. C. Dunand, NiTi porous structure with 3D interconnected microchannels using steel wire spaceholders, Materials Science and Engineering A, 634 (2015), 153-160, doi:10.1016/j.msea.2014.12.088

${ }^{5}$ X. Xu, X. Lin, M. Yang, J. Chen, W. Huang, Microstructure evolution in laser solid forming of Ti-50 wt\% Ni alloy, Journal of Alloys and Compounds, 480 (2009), 782-787, doi:10.1016/j.jallcom. 2009.02.056

${ }^{6}$ D. D. Radev, Mechanical synthesis of nanostructured titanium-nickel alloys, Advanced Powder Technology, 21 (2010), 477-482, doi:10.1016/j.apt.2010.01.010

${ }^{7}$ J. W. Hu, Numerical simulation for the behavior of superelastic shape memory alloys, Journal of Mechanical Science and Technology, 27 (2013) 2, 381-386, doi:10.1007/s12206-012-1268-8

${ }^{8}$ M. Köhl, M. Bram, A. Moser, H. P. Buchkremer, T. Beck, D. Stöver, Characterization of porous, net-shaped NiTi alloy regarding its damping and energy-absorbing capacity, Materials Science and Engineering A, 528 (2011), 2454-2462, doi:10.1016/j.msea.2010. 11.055

${ }^{9}$ J. Li, H. Yang, H. Wang, J. Ruan, Low elastic modulus titanium-nickel scaffolds for bone implants, Materials Science and Engineering C, 34 (2014) 110-114, doi:10.1016/j.msec.2013.08.043

${ }^{10}$ T. Bormann, G. Schulz, H. Deyhle, F. Beckmann, M. D. Wild, J. Küffer, C. Münch, W. Hoffmann, B. Müller, Combining micro computed tomography and three-dimensional registration to evaluate local strains in shape memory scaffolds, Acta Biomaterialia, 10 (2014), 1024-1034, doi:10.1016/j.actbio.2013.11.007

${ }^{11}$ A. J. Neurohr, D. C. Dunand, Mechanical anisotropy of shape-memory NiTi with two-dimensional networks of micro-channels, Acta Materialia, 59 (2011), 4616-4630, doi:10.1016/j.actamat.2011. 04.007
${ }^{12}$ S. Wu, C. Y. Chung, X. Liu, P. K. Chu, J. P. Y. Ho, C. L. Chu, Y. L. Chan, K. W. K. Yeung, W. W. Lu, K. M. C. Cheung, K. D. K. Luk, Pore formation mechanism and characterization of porous NiTi shape memory alloys synthesized by capsule-free hot isostatic pressing, Acta Materialia, 55 (2007) 10, 3437-3451, doi:10.1016/ j.actamat.2007.01.045

${ }^{13}$ S. Wisutmethangoona, N. Denmud, L. Sikong, Characteristics and compressive properties of porous NiTi alloy synthesized by SHS technique, Materials Science and Engineering A, 515 (2009), 93-97, doi:10.1016/j.msea.2009.02.055

${ }^{14}$ P. Novák, L. Mejzlíková, A. Michalcová, J. Capek, P. Beran, D. Vojt, Effect of SHS conditions on microstructure of NiTi shape memory alloy, Intermetallics, 42 (2013), 85-91, doi:10.1016/j.intermet.2013. 05.015

${ }^{15}$ G. Hu, Z. Lixiang, F. Yunliang, L. Yanhong, Fabrication of high porous NiTi shape memory alloy by metal injection molding, Journal of Materials Processing Technology, 206 (2008), 395-399, doi:10.1016/j.jmatprotec.2007.12.044

${ }^{16}$ A. Biswas, Porous NiTi by thermal explosion mode of SHS: processing, mechanism and generation of single phase microstructure, Acta Materialia, 53 (2005) 5, 1415-1425, doi:10.1016/j.actamat. 2004.11.036

${ }^{17}$ P. Novák, V. Vojtěch, Z. Pecenová, F. Průša, P. Pokorný, D. Deduytsche, C. Detavernier, A. Bernatiková, P. Salvetr, A. Knaislová, K. Nová, L. Jaworska, Formation of Ni-Ti intermetallics during reactive sintering at $800-900^{\circ} \mathrm{C}$, Materiali in Tehnologije / Materials and Technology, 51 (2017) 4, 679-685, doi:10.17222/mit.2016.257

${ }^{18}$ G. Chen, K. D. Liss, P. Cao, An in situ Study of NiTi Powder Sintering Using Neutron Diffraction, Metals, 5 (2015), 530-546, doi: 10.3390/met5020530

${ }^{19}$ S. A. Hosseini, M. Alizadeh, A. Ghasemi, M. A. Meshkot, Highly Porous NiTi with Isotropic Pore Morphology Fabricated by Self-Propagated High-Temperature Synthesis, Journal of Materials Engineering and Performance, 22 (2013) 2, 405-409, doi:10.1007/ s11665-012-0289-X

${ }^{20}$ J. Y. Xiong, Y. C. Li, X. J. Wang, P. D. Hodgson, C. E. Wen, Titanium-Nickel Shape Memory Alloy Foams for Bone Tissue Engineering, Journal of the Mechanical Behavior of Biomedical Materials, 1 (2008), 269-273, doi:10.1016/j.jmbbm.2007.09.003

${ }^{21}$ J. L. Xu, L. Z. Bao, A. H. Liu, X. J. Jin, Y. X. Tong, J. M. Luo, Z. C. Zhong, Y. F. Zheng, Microstructure, mechanical properties and superelasticity of biomedical porous NiTi alloy prepared by microwave sintering, Materials Science and Engineering C, 46 (2015), 387-393, doi:10.1016/j.msec.2014.10.053

${ }^{22}$ M. Arciniegas, C. Aparicio, J. M. Manero, F. J. Gil, Low elastic modulus metals for joint prosthesis: Tantalum and nickel-titanium foams, Journal of the European Ceramic Society, 27 (2007) 11, 3391-3398, doi:10.1016/j.jeurceramsoc.2007.02.184 